DOI: $10.2478 /$ rrlm-2014-0030

\title{
The neuroendocrine markers assay and the glycemia profile in patients with neuroendocrine tumors under octreotide therapy: a 2 years study
}

\section{Determinarea markerilor neuroendocrini şi a profilului glicemic la pacienţii cu tumori neuroendocrine în tratament cu octreotid}

\author{
Cătălina Poiană ${ }^{1,2^{*}}$, Diana Păun ${ }^{1,2}$, Mara Carsote $^{1,2}$ \\ 1. "Carol Davila" University of Medicine and Pharmacy, Bucharest, România \\ 2. "C.I.Parhon" National Institute of Endocrinology, Bucharest, România
}

\begin{abstract}
The neuroendocrine tumors (NETS) are more frequent during the last decades. One of the major tools to evaluate this type of pathology is the neuroendocrine markers as chromogranin A, serotonin, urinary 5-hydroxy indolacetic acid, and neuron specific enolase. They change related to the disease progression, regardless therapy. Some of the drugs that are used for NETs as somatostatin analogs (for example octreotide) might interfere with glucose metabolism. Objectives. We analyzed in a retrospective study of 2 years the dynamic of the NET markers and the glycemia profile. Material and Methods. All the patients had at least one assay per year. Results. 9 patients were included ( 5 women and 4 men), with a mean age of 57.33 years. They were treated before the study with octreotide for 18 +/- 14.69 months. The dose of octreotide varied from 20 to $50 \mathrm{mg}$, monthly. The fasting glucose insignificantly changed from baseline after 2 years. No new case of diabetes was registered. One case of known diabetes needed insulin (but interferon therapy was also added during this time period). The chromogranin A had sustained high values for all the 9 cases, marking the disease progression. The neuron specific enolase significantly increased, and the serum serotonin as well as the 5HIIA was much higher in 2 cases with aggressive carcinoid symptoms. Conclusion. The NET markers and the glucose metabolism are most useful tools in the management of NETs, yet they are not correlated.
\end{abstract}

Keywords: chromogranin A, neuroendocrine tumor, serotonin

\section{Rezumat}

Tumorile neuroendocrine (NET) sunt mult mai frecvente în ultimele decade. Unul din intrumentele majore de evaluare în această patologie este reprezentat de dozarea markerilor neuroendocrini precum cromogranina A, serotonina, acidul 5-hidroxi indolacetic urinar şi enolaza neuronal specifică. Aceştia se schimbă cu progresia tumorală, indiferent de terapie. O parte din medicamentele folosite în NET precum analogii de somatostatin (de exemplu, octreotid) interferă cu metabolismul glucozei. Obiectiv. Am analizat intr-un studiu retrospectiv de-a

*Corresponding author: Cătălina Poiană, Carol Davila University of Medicine and Pharmacy Bucharest, România, e-mail: endoparhon@gmail.com 
lungul a 2 ani dinamica markerilor NET şi profilul glicemic. Material si metode.Toţi pacienţii au avut cel puţin o evaluare pe an. Rezultate. 9 pacienţi au fost incluşi (5 femei şi 4 bărbaţi), cu o vârstă medie de 57,33 de ani. Perioada de tratament anterior cu octreotid a fost de 18 +/- 14,69 de luni. Doza de octreotid a variat de la 20 la $50 \mathrm{mg}$ lunar. Glicemia s-a modificat nesemnificativ de la bază după 2 ani. Nu s-a înregistrat nici un caz nou de diabet. $O$ pacientă a necesitat insulină pentru diabetul preexistent (dar între timp s-a adaugat şi terapie cu interferon) Cromogranina A a avut valori mari sustinute pentru toate cele 9 cazuri, sugerând progresia bolii. Enolaza neuronal specifică a crescut semnificativ iar serotonina serică şi 5HIIA au crescut considerabil în 2 cazuri cu simptome severe de sindrom carcinoid. Concluzie. Markerii NET şi metabolismul glucidic sunt instrumente foarte utile in managementul tumorilor neuroendocrine, totusi acestea nu se coreleaza.

Cuvinte cheie: cromogranina A, tumora neuroendocrina, serotonina

Received: $24^{\text {th }}$ August 2013; Accepted: $5^{\text {th }}$ August 2014; Published: $1^{\text {st }}$ September 2014.

\section{Introduction}

Neuroendocrine tumors (NETs) represent a dynamic, new field of interest. For the last decades, more information was obtained about the subject, while better investigation tools (including the neuroendocrine markers) were developed and used. A real increased frequency of the NETs was registered. (1)

The typical "carcinoid tumors" or the general name of "cancer" are no longer commonly used, since the European Neuroendocrine Tumors Society (ENETS) developed a standard yet dynamic classification of the NETs. $(2,3)$ The tumors vary from G1 NET (with good prognosis) to G3 NET (extremely aggressive). The classical carcinoid syndrome is less frequent that the NETs. Neuroendocrine markers are high in the carcinoid syndrome because of the liver metastases that impair hepatic function. (4) Generally, apart from the ENETS staging based on histological and immunochemistry phenotype, the other two major aspects are: the primary site of the tumor (one third of cases has an actually unknown primary site), and the neuroendocrine markers assay. (5)

Laboratory tests are crucial in NETs since they are useful in the prognosis and therapy decisions: serum chromogranin $\mathrm{A}$, serum serotonin, and urinary 5-hydroxy indolacetic acid (5-HIIA). Chromogranin A is more sensitive than specific. It may increase in different type of tumors as ad- renal tumors or classic malignant tumors. It is the best marker for follow-up and for adequate management regarding therapy options. (6) The serotonin is mainly related to the symptoms of carcinoid syndrome, but not all the NETs produce it. The 5HIIA is also related to the serotonin metabolism and carcinoid aspects. False positive markers are frequently registered in omeprazole use, renal failure, the lack of adequate liquid intake (for chromogranin A), different type of food (for 5HIIA or serotonin). (7) A fourth neuroendocrine marker, the neuron specific enolase (NSE), is less used and also a smaller number of NETs are NSE positive. In NSE positive cases, this marker might be a more reliable marker, with higher specificity than any other mentioned neuroendocrine markers.

A very important aspect in the use of the neuroendocrine markers in current clinical practice is the evaluation of NETs therapy like chemotherapy, surgery, somatostatin analogues as octreotide or lanreotide. The therapy is very well tolerated, in opposite to the chemotherapy, and only some small reactions are registered, such as the risk of glucose metabolism disturbances (based on lowering insulin release), and gallbladder sludge.

Our objective was to evaluate the dynamic of the neuroendocrine markers in NETs and glucose metabolism in cases of patients treated with long released formula of somatostatin analogs. 


\section{Material and Methods}

This is a retrospective observational (non-interventional) study in patients diagnosed with neuroendocrine tumors, and treated in the " $\mathrm{C}$. I. Parhon" National Institute of Endocrinology from Bucharest, Romania, between 2011 and 2013. NETs were confirmed by histological (and immunochemistry profile) examination of the primary tumor or metastases, after surgery or hepatic biopsy. They were classified based on ENETS grading (G1, G2 or G3).

The neuroendocrine markers were assessed every 6 to 12 months for 2 years in each patient: chromogranin A (ELISA, LaborDiagnostika-Nord, Germany), serotonin (ELISA, LaborDiagnostika-Nord, Germany), NSE (immunoradiometric assay - IRMA), and 5HIIA (HPLC). Peripheral blood was drawn by vein puncture. Plasma was obtained by collecting blood in heparin-containing vials. Serum was obtained by allowing blood to clot at room temperature. Aliquots of 24-hour urine samples for 5HIIA were used immediately for the 5HIIA assay. Three days before the start of urine sampling, there were some diet restrictions for the patients (bananas, pineapples, kiwi, nuts etc.), and no methyldopa containing drugs, neither sympathomimetic amines were used.

The fasting glycaemia and glycated hemoglobin (HbAlc- HPLC method) were also performed, every time the patient had the neuroendocrine markers assessed. During the study, the patients were followed-up by clinical evaluation, as well as imagistic scan as computed tomography or magnetic resonance.

The including criteria were:

1. Confirmed diagnosis of NETs, regardless the type or grading;

2. Treatment with somatostatin analogue (Octreotide LAR, monthly injection), regardless the dose or the time since starting this kind of drug, and regardless other treatment options such as chemotherapy or interferons;
3. Age at diagnosis of NETs of 30 years or older. The excluding criteria were:

1. The lack of informed consent of the patient;

2. The patients who could not be evaluated for at least 2 years according to the study design were not enrolled (including the patients who died during that time of period).

The informed consent of the patients was obtained. Each patient agreed that their clinical data may be used in studies. Simple descriptive statistic parameters were used (as mean, standard deviation, ranges). The Spearman correlation (SPSS 17) was used for the statistical analysis (statistical significance at $\mathrm{p}$ value less than 0.05 ).

\section{Results}

Out of a database of 42 patients with NETs, 9 patients met the criteria of this study design. The female / male ratio was $5 / 4$. The mean age at diagnosis of NETs was: $55.33+/-15.22$ years (ranges between 33 and 74 years). Except for one case with classical symptoms of carcinoid syndrome 72 months before the actual diagnosis, all the patients were confirmed with NET based on histological and immunochemistry profile, immediately after surgery of the tumor or metastases or hepatic biopsy. Another 2/9 had mild atypical symptoms of carcinoid syndrome.

$1 / 9$ of the patients had been treated with peptide receptor radionuclide therapy (PRRT); 2/9 of the patients had interferon therapy, and 2/9 of patients had chemotherapy associated with octreotide therapy. All the patients had metastases at the moment when octreotide treatment was started. The G1 / G2 / G3 percent of tumors was: $11.11 \% / 55.55 \% / 33.33 \%$. The percent of each primary site was: 2/9 lung, 2/9 ileum, 2/9 pancreas, $1 / 9$ stomach, and 2/9 with unknown primary site. $5 / 9$ of the cases had primary surgery for the tumor.

All the patients were under therapy with octreotide LAR (deeply muscle injections), with 
doses from $20 \mathrm{mg}$ / monthly up to $50 \mathrm{mg}$ / monthly. The drug was started before the study within $18+/-14.69$ months. The patients' age at study inclusion was: $57.33+/-15.25$ years. $3 / 9$ of the patients had diabetes mellitus at the beginning of the therapy $(2 / 3$ of these had insulin-dependent type 2 diabetes mellitus, and one third had secondary diabetes due to pancreatectomy, treated with oral antidiabetic agents ). No pre-diabetes case was known at baseline.

The starting dose of octreotide was $20 \mathrm{mg}$ per months in $5 / 9$ of cases, $3 / 9$ had $30 \mathrm{mg}$ per months and 1/9 had $40 \mathrm{mg}$ per months as the dose of octreotide at baseline of the study. Except for one case, all the patients increased the dose of octreotide after one year because of the evident tumor progression at computer tomography scan.

The fasting glucose was at baseline at beginning of the study, as well as glycated hemoglobin after the first year, and data after the second year is shown in Table I. No new case of diabetes was registered. ADA 2014 Guidelines regarding the Criteria for Diabetes Diagnosis specifies that diabetes mellitus is at the fasting glucose $\geq$ $126 \mathrm{mg} / \mathrm{dL}$. Except for the 3 cases of known di- abetes, we had none according to these criteria (after the first year, neither after the second year of therapy). Based on the ADA 2014 for diabetes diagnosis using $\mathrm{HbA} 1 \mathrm{c}$ of $\geq 6.5 \%$, except for the 3 already known cases, only one (case number 1 in the Table I) met the criteria of diabetes. But, in this particular case (as suggested by ADA 2014 Guidelines) the value of HbA1C was not confirmed at repeated test (in a different laboratory), neither by glycaemia levels.

The case of diabetes treated with oral antidiabetic agents needed insulin therapy for 12 months because of the major increase of $\mathrm{HbAlc}$ but octreotide therapy was associated with a second line therapy as interferon, and the insulin therapy was no longer necessary 3 months after stopping interferon.

The neuroendocrine markers had the pattern presented in Table II. An ascendant trend is remarkable in most of the cases despite octreotide therapy. Except of 2 cases, all the NETs had abnormal high chromogranin A at baseline (above the normal limit of $100 \mathrm{ng} / \mathrm{mL}$ ). The same two cases had normal chromogranin A after 2 years of octreotide. The highest chromogranin value was registered in one female case with pancreat-

Table I. Patients' data and glucose profile (normal fasting glucose level up to $100 \mathrm{mg} / \mathrm{dL}$, and normal $\mathrm{Hb}$ A1c up to $6 \%$ based our laboratory; diagnosis of diabetes mellitus at fasting glucose $\geq 126 \mathrm{mg} / \mathrm{dL}$ amd $\mathrm{Hb}$ A1c $\geq 6.5 \%$, based on ADA 2014)

\begin{tabular}{ccccccccc}
\hline $\begin{array}{c}\text { Patient } \\
\text { number }\end{array}$ & $\begin{array}{c}\text { Female/ } \\
\text { male }\end{array}$ & $\begin{array}{c}\text { Diabetes at } \\
\text { baseline }\end{array}$ & \multicolumn{3}{c}{ Glycemia (mg/dL) } & \multicolumn{3}{c}{ HbA1c (\%) } \\
& & Baseline & after 1y & after 2 y & Baseline & after 1y & after 2 y \\
\hline 1 & $\mathrm{~F}$ & no & 98 & 94 & 104 & 6 & 5.88 & 6.5 \\
\hline 2 & $\mathrm{~F}$ & $+($ insulin) & 158 & 140 & 126 & 7.1 & 7.4 & 6.7 \\
\hline 3 & $\mathrm{~F}$ & $+($ oral drugs $)$ & 154 & 225 & 154 & 5.85 & 10.46 & 6.97 \\
\hline 4 & $\mathrm{M}$ & no & 113 & 107 & 125 & 4.5 & 4.9 & 6.1 \\
\hline 5 & $\mathrm{M}$ & no & 86 & 84 & 101 & 4.3 & 4.4 & 4.9 \\
\hline 6 & $\mathrm{M}$ & no & 89 & 118 & 101 & 5.6 & 5.8 & 5.9 \\
\hline 7 & $\mathrm{~F}$ & $+($ insulin $)$ & 91 & 110 & 102 & 6.7 & 6.8 & 6.9 \\
\hline 8 & $\mathrm{M}$ & no & 88 & 106 & 110 & 5.9 & 6 & 6.01 \\
\hline 9 & $\mathrm{~F}$ & no & 93 & 108 & 98 & 5.8 & 6 & 6.2 \\
\hline
\end{tabular}


Table II. The neuroendocrine markers profile for 2 years

\begin{tabular}{|c|c|c|c|c|c|c|c|c|c|c|c|c|}
\hline & \multicolumn{3}{|c|}{$\begin{array}{c}\text { Chromogranin } A \\
(n g / d L)\end{array}$} & \multicolumn{3}{|c|}{$\begin{array}{c}\text { Serotonin } \\
(\mathrm{ng} / \mathrm{mL})\end{array}$} & \multicolumn{3}{|c|}{$\begin{array}{c}\text { NSE } \\
(\mathbf{n g} / \mathbf{m L})\end{array}$} & \multicolumn{3}{|c|}{$\begin{array}{c}\text { 5HIIA } \\
(\mathrm{mg} / 24 \mathrm{~h})\end{array}$} \\
\hline & Baseline & $\begin{array}{c}\text { after } \\
1 \mathrm{y}\end{array}$ & $\begin{array}{l}\text { after } \\
2 \mathbf{y}\end{array}$ & Baseline & $\begin{array}{c}\text { after } \\
1 \mathbf{y}\end{array}$ & $\begin{array}{l}\text { after } \\
2 \mathbf{y}\end{array}$ & Baseline & $\begin{array}{c}\text { after } \\
1 \mathrm{y}\end{array}$ & $\begin{array}{c}\text { after } \\
2 y\end{array}$ & Baseline & $\begin{array}{l}\text { after } \\
1 y\end{array}$ & $\begin{array}{c}\text { after } \\
2 \mathbf{y}\end{array}$ \\
\hline 1 & 97 & 57 & 45 & 219 & 207 & 62 & 4.53 & 14 & 8.1 & 1.37 & 4.5 & 2.1 \\
\hline 2 & 1500 & 1500 & 1500 & 220 & 272 & 80 & 18 & 21 & 26 & 11.2 & 12 & 9.2 \\
\hline 3 & 40 & 69 & 30 & 347 & 351 & 252 & 8 & 9 & 9 & 1 & 3 & 1 \\
\hline 4 & 252 & 557 & 137 & 888 & 665 & 900 & 2 & 10 & 9 & 25 & 15 & 17 \\
\hline 5 & 373 & 144 & 160 & 102 & 112 & 140 & 47 & 35 & 30 & 5 & 6 & 6.5 \\
\hline 6 & 244 & 210 & 199 & 963 & 3402 & 882 & 12.1 & 15 & 18 & 8 & 4 & 5 \\
\hline 7 & 240 & 300 & 301 & 304 & 389 & 390 & 6 & 9 & 11 & 5 & 5.6 & 5.8 \\
\hline 8 & 200 & 250 & 304 & 240 & 245 & 198 & 3.4 & 5.6 & 10.1 & 4 & 7 & 7.9 \\
\hline 9 & 201 & 198 & 278 & 298 & 344 & 490 & 4.6 & 8 & 11.1 & 5.8 & 6.5 & 8.9 \\
\hline
\end{tabular}

ic NET and terminal disease that also associated a mild renal insufficiency (a level of $1500 \mathrm{ng} /$ $\mathrm{mL}) .3 / 9$ of the patients had ENS above the normal limits of normal, the others had normal NSE at point 0 but after 2 years $6 / 9$ had abnormal levels of NSE despite the therapy. In cases with carcinoid syndrome, we did not have a specific pattern of blood and urine testing, meaning that the values we registered were not necessarily after a carcinoid crisis. No correlation was found between the dose of monthly octreotide and fasting glycaemia, neither HbA1c ( $p>0.05)$, neither between these two glucose metabolism parameters and chromogranin A, serotonin, NSE or 5HIIA: chromogranin A (at baseline) and glycaemia: $\mathrm{r}=-0.05, \mathrm{p}=0.89$, and HbA1c 1.18 , respectively 0.63 ; chromogranin A (after first year) and glycaemia 0.28 , respectively 0.46 , and $\mathrm{HbA} 1 \mathrm{c} 0.11$, respectively 0.76 ; chromogranin A (after second year) and glycaemia -0.14 , respectively 0.71 , and $\mathrm{HbA1c}-0.08$, respectively 0.83 ; serotonin (at baseline) and glycaemia: 0.18 , respectively 0.63 , and $\mathrm{HbA} 1 \mathrm{c}-0.21$, respectively 0.57 ; serotonin (after first year) and glycaemia 0.61 , respectively 0.07 , and $\mathrm{HbA} 1 \mathrm{c} 0.10$, respectively 0.79 ; serotonin (after second year) and glycaemia 0.1, respectively 0.7 , and $\mathrm{HbA} 1 \mathrm{c} 0.08$, respectively 0.7 ; NSE (at baseline) and glycaemia: -0.1 , respectively 0.79 , and $\mathrm{HbA} 1 \mathrm{c}-0.03$, respectively 0.93; NSE (after first year) and glycaemia -0.09 , respectively 0.81 , and $\mathrm{HbA} 1 \mathrm{c}-0.41$, respectively 0.27 ; NSE (after second year) and glycaemia -0.43 , respectively 0.24 , and HbA1c -0.42 , respectively 0.25 ; 5HIIA (at baseline) and glycaemia: 0.15 , respectively 0.68 , and $\mathrm{HbA} 1 \mathrm{c}-0.20$, respectively 0.58 ; 5HIIA (after first year) and glycaemia -0.26 , respectively 0.48 , and $\mathrm{HbA} 1 \mathrm{c}$ -0.19 , respectively 0.62 ; 5HIIA (after second year) and glycaemia -0.4 , respectively 0.2 , and HbAlc -0.26 , respectively 0.48 .

\section{Discussions}

Fasting glycaemia and $\mathrm{HbAlc}$ during the therapy with octreotid LAR for 2 years were similar, despite the fact that most of the patients had increased dose of octreotide. The HbAlc had some variations but after 2 years of therapy with somatostatin analog, the levels were significantly changed.

Chromogranin A is an acid glycoprotein of 439 amino acids, and has a molecular weight of $48 \mathrm{kD}$. Its function under normal circumstances 
is not completely understood. It is generated in secretory granules of foregut, midgut, and hindgut NETs, and it represents an important tissue serum marker. (8) In the particular case of neuroendocrine tumors it is useful for disease progression assessment. In this study the mean values of chromogranin A were above the normal limits and remained so after 24 months. In two cases (associated with carcinoid syndrome) the serotonin and 5HIIA significantly increased. The NSE significantly increased from baseline to the end, probably associated to the imagistic evolution of the tumors, and the values were less influenced by the higher octreotide dose.

We would like to mention some particular situations we found in this study. One case developed transitory higher insulin need because of the interferon therapy that was used during the study. No case of new diabetes mellitus was registered. In one case with ulcer symptoms, the patient aggressively used omeprazole and the chromogranin A increased and normalized when stopping the digestive therapy within 3 months. In one female case with pancreatic NET, the serum chromogranin A was above the normal limit of normal in successive measurements because of her associate mild renal failure.

In this study, the evolution of the neuroendocrine markers and glucose profile was not associated with a particular type of aggressive tumor or a particular type of grading. It is known that the neuroendocrine tumors might suddenly change their behavior, in association or not with the changes (as resistance) as response to the therapy. $(9,10)$ Generally, the analog of somatostatin induce hyperglycaemia, thus they are used in medication induced hypoglycaemia but it seems that their use in NETs therapy are not consistent in aggravating the glucose tolerance. (11) The connection between the NETs and metabolic profile as glucose metabolism is done via hormonal (biological) therapy as octreotide, thus some nutrition and diabetes specialists should be involved. We would also want to mention that wide areas of metabolic (non-oncologic) complications have recently been described in association with NETs as calcium metabolism disturbances (that are not related to metastasis), or osteoporosis. (12-14)

As limits of the study we mention the small number of the patients but this topic is relatively new in Romania because the therapy with analogs of somatostatin was not available up to 2008, and also (based on the fact that these are clinical observations) no index of insulin resistance (HOMA-IR calculation) was introduced. The only prescribers for NETs are the endocrinologists and oncologists in our country, and there is no official database or report regarding the incidence and clinical phenotype of NETs in this area. We also mention that the small number of patients included in our study is related to the 2 years of the study because most of the patients diagnosed with NETs and treated with octreotide have an advanced disease and a low survivor rate. Probably, a larger database will clarify if the glucose metabolism is severely impaired while the patients are treated with analogs of somatostatin. So far, based on our observations, this aspect is more likely a recommendation of follow -up the patients than a severe side effect.

The glucose metabolism might be affected because the octreotide (via somatostatin) inhibits the insulin secretion. This theoretical aspect was not registered in any patient treated with octreotide. The early observations up to most recent ones reported 20 up to $50 \%$ of cases with glucose metabolism anomalies (mainly on third of the patients). It is difficult to anticipate which patient will develop such profile. Probably this aspect is related to the genetic predisposition, metabolic phenotype (as weight, etc.) of each patient, pancreas involvement as primary or secondary site of the tumor, the others drugs as interpherone, the others cytokines or kinines se- 
creted by the tumor (most of them are not assessed in clinical current practice) etc). (15-17)

We found no correlation between the neuroendocrine markers and glucose disturbances (the values of fasting glucose or $\mathrm{HbA} 1 \mathrm{c}$ ) in patients with neuroendocrine tumors treated with octreotide LAR for neuroendocrine tumors for two years but the blood glucose profile is imperious to the periodically checked up in these situations since the somatostatin inhibits the pancreas secretion of insulin in normal conditions.

\section{References}

1. Barakat MT, Meeran L, Bloom SR. Neuroendocrine tumors. Endocr Relat Cancer. 2004 Mar;11(1):1-18. DOI: 10.1677/erc. 0.0110001

2. Oberndorfer S. Karzinoide tumoren des dunndarms. Frank Z Pathol. 1907;1:426-432.

3. Salazar R, Wiedenmann B, Rindi G, Ruszniewski P. ENETS 2011 Consensus Guidelines for the Management of Patients with Digestive Neuroendocrine Tumors: An Update. Neuroendocrinology. 2012;95(2):713. DOI: $10.1159 / 000335600$

4. Pinchot S, Holen K, Sippel R, Chen H. Carcinoid Tumors. Oncologist. 2008;13(12):1255-1269. DOI: 10.1634/theoncologist.2008-0207

5. Bellizzi AM. Assigning site of origin in metastatic neuroendocrine neoplasms: a clinically significant application of diagnosis immunohistochemistry. Adv Anat Pathol. 2013 Sep;20(5):285-314. DOI: 10.1097/ PAP.0b013e3182a2dc67

6. Fisher-Colbrie R, Hagn C, Schober M. Chromogranins A, B, C: widespread consitituents of secretory vesicles. Ann N Y Acad Sci. 1987;493:120-34. DOI: 10.1111/ j.1749-6632.1987.tb27189.x

7. Bajetta E, Ferrari L, Martinetti A, Celio L, Procopio $\mathrm{G}$, Artale S, et al. Chromogranin A, neuron specific enolase, carcinoembryonic antigen, and hydroxyindole acetic acid evaluation in patients with neuroendocrine tumors. Cancer. 1999;86(5):858-865. DOI: 10.1002/ (SICI)1097-0142(19990901)86:5<858::AID-CNCR23>3.0.CO;2-8
8. Iacangelo AL, Eiden LE. Chromogranin A: current status as a precursor for bioactive peptide and a granulogenic/sorting factor in the regulated secretory pathway. Regul Pept. 1995 Aug 22;58(3):65-88. DOI: 10.1016/0167-0115(95)00069-N

9. Poiană C, Neamţu MC, Avramescu ET, Carşote M, Trifănescu R, Terzea D, et al. The poor prognosis factors in G2 neuroendocrine tumor. Rom J Morphol Embryol. 2013;54(3 Suppl):717-20.

10. Poiană C, Neamţu MC, Avramescu ET, Carşote M, Trifănescu R, Terzea $\mathrm{D}$, et al. The dedifferentiation of neuroendocrine tumor metastases: myth or reality? Rom J Morphol Embryol. 2013;54(1):201-3.

11. Groth CM, Banzon ER. Octreotide for the treatment of hypoglycemia after insulin glargine overdose. J Emerg Med. 2013 Aug;45(2):194-8. DOI: 10.1016/j. jemermed.2012.11.099

12. Vinik Al, Silva MP, Woltering EA, Go VL, Warner R, Caplin M. Biochemical testing for neuroendocrine tumors. Pancreas. 2009;38(8):876-89. DOI: 10.1097/ MPA.0b013e3181bc0e77

13. Lawrence B, Gustafsson Bl, Kidd M, Pavel M, Svejda $\mathrm{B}$, Modlin M. The clinical relevance of chromogranin $\mathrm{A}$ as a biomarker for gastroenteropancreatic neuroendocrine tumors. Endocrinol Metab Clin North Am 2011;40(1):111-34. DOI: 10.1016/j.ecl.2010.12.001

14. Poiană C, Carşote M, Neamtu MC, Avramescu ET, Vasilescu F, Terzea D, et al. Well-differentiated neuroendocrine tumor and osteoporosis: incidental finding? Rom J Morphol Embryol. 2013;54(4):1169-71.

15. Oberg K, Norheim I, Theodorsson E. Treatment of malignant midgut carcinoid tumours with a long-acting somatostatin analogue octreotide. Acta Oncol. 1991;30(4):503-7. DOI: 10.3109/02841869109092409

16. Panzuto F, Di Fonzo M, Iannicelli E, Sciuto R, Maini $\mathrm{CL}$, Capurso $\mathrm{G}$, et al. Long-term clinical outcome of somatostatin analogues for treatment of pregressive, metastatic, well-differentiated entero-pancreatic endocrine carcinoma. Ann Oncol. 2006;17(3):461-6. DOI: 10.1093/annonc/mdj113

17. Butturini G, Bettini R, Missiaglia E, Mantovani W, Dalai I, Capelli P, et al. Predictive factors of efficacy of the somatostatin analogue octreotide as first line therapy for advanced pancreatic endocrine carcinoma. Endocr Relat Cancer. 2006;13(4):1213-21. DOI: 10.1677/ erc. 1.01200 